\title{
SHEANNA MURRAY
}

Sapienza University of Rome

\section{Identities in Roman Macedonia during the Early Imperial Period}

This paper focuses on the impact of the Roman presence in Macedonia on the collective identities of the local population from the beginning of Roman rule in the region in 167 BC until the early $3^{\text {rd }}$ century $A D$. The societal changes taking place during the first three and a half centuries have been outlined using the available epigraphic, numismatic and onomastic evidence to analyse the evolving identities of the Macedonians and the new forms of expression of these identities. The approach taken in this paper is not one of Hellenisation or Romanisation but of acculturation, focussing on the identities of the Macedonian people that adapted and evolved in relation to the new political and cultural environment.

Keywords: identities, acculturation, Roman Macedonia, euergetism, emperor cult, associations

Throughout our lives we associate ourselves with several different groups: age groups, gender, religion and ethnicity, to name a few. Out of all of these groups it is those with a strong cultural significance such as a nation, a religion or an ethnicity that have a stronger cultural identity. ${ }^{1}$ It is because individuals within these groups form a bond based on their shared roots that they trace back to centuries or even millennia in the past and this gives them a sense of being distinct from the rest. In this paper I am concerned with the collective Macedonian identity how the Macedonians expressed rootedness to their cultural origins while adapting themselves to Roman rule and how this expression changed over time within the context of the empire.

When Perseus, the last king of Macedonia was defeated by the Romans in $167 \mathrm{BC}$, the kingdom had well established political and religious institutions in each city and a myth of origin that connected the

\footnotetext{
${ }^{1}$ HARRIS (1995: 131).
} 
Macedonians with their Greek roots. The republican period brought minimal societal changes, with small communities of Romans who were regarded as foreigners by the locals, settled in the cities. But the society unverwent greater changes during the imperial period. At the beginning of Augustus' rule there was a large influx of traders and veterans from Rome who settled in Macedonia and integrated themselves into the social and political lives of the cities and their descendants were no longer regarded as foreigners. Since both the Romans and the Macedonians had their own distinct identity, neither completely assimilated into the other. But centuries of Roman presence did cause their identities to intermingle making it increasingly difficult to draw a clear distinction between the two. This is owing to the fact that identities are not static but are in constant flux in relation to the external circumstances and as identities change, so do their means of expression. The change in identities is the central focus of this paper. By outlining the socio-political changes that took place in Macedonia from the late Republican period until early $3^{\text {rd }}$ century $A D,{ }^{2}$ I have tried to define the changes that took place in the collective Macedonian identity and their new forms of expression through cults, rituals, changes in the naming system and acts of benefactions. Even by analysing these public forms of expression of identities, it is impossible to ascertain how individuals really felt but it is possible to discern the logic behind their actions. ${ }^{3}$ That is what I aim to do in this paper.

\section{Roman presence and societal changes during the Republican period}

Before the Roman conquest Macedonia was a monarchy tracing its royal lineage back to the $7^{\text {th }}$ century BC. While until the reign of Philip II Macedonia remained a small kingdom seldom mentioned in literary sources and always in relation to the events occurring in the cities of southern Greece, Philip and particularly his son Alexander III transformed Mace-

\footnotetext{
2 The reason I have chosen this period is because the Constitutio Antoniniana in 212 AD led to the decline in importance of Roman citizenship, causing societal changes that are out of the scope of this paper.

${ }^{3}$ MiLlaR (1984: 40).
} 
donia into a glorious empire which was remembered with pride and admiration centuries later not only by the Macedonians but also the Romans.

The Temenids were believed to be the descendants of Heracles and thus related to Zeus but members of the royal family were never worshipped as gods. However, it was Philip II who was the first to possibly hint at his own divination. Here I should discuss briefly the worship of kings in Macedonia during the monarchical period because religion, particularly ruler worship, was an integral component of Macedonian society that helped the people of the province to adjust to Roman rule during the imperial period. And while it is known that the origins of the ruler cult during this period lay in Hellenistic ruler cults practised by dynasties such as the Ptolemies who started their own central dynastic cult involving the worship of Alexander and the Ptolemaic rulers, ${ }^{4}$ there is no evidence in Macedonia suggesting a centrally organised cult dedicated to the kings, either living or dead. Nevertheless, there is sporadic evidence from a few cities indicating that the dedication of divine honours to kings was purely a civic affair and often for purposes that were not religious but political.

Philip II's actions suggesting his divine inclinations have been debated and interpreted in various ways. Not only did he display statues of himself and his family members made of gold and ivory at the sanctuary of Olympia but also displayed a statue of himself at his daughter's wedding seated amongst the twelve Olympian gods (ironically on the day that he died). It is possible that he was emphasising his divine nature or sending the message that his power was similar to that of the gods, ${ }^{5}$ but as Baynham suggests, he may not have intended actual worship. ${ }^{6}$ This is supported by the fact that he built the Philippeon outside Macedonia, most likely intending to display his power to the southern Greeks. If he intended to be worshipped by his people, he would have also displayed his divine connections elsewhere within the Macedonian cities such as Dion which was known for its religious significance within

\footnotetext{
${ }^{4}$ CHANIOTIS (2003: 434-435).

${ }^{5}$ CARNEY (2000: 25).

${ }^{6}$ BAYNHAM (1994: 38).
} 
the kingdom. But it was not commonplace in Macedonia during this period for a king to propagate a cult dedicated to himself nor was it expected of people to grant him such honours. However, Amphipolis after its conquest in 357 BC, Philippi and Philippopolis (in Thrace) which were founded or re-founded by Philip dedicated cults to him during his lifetime, probably honouring him as founder. ${ }^{7}$ These cities dedicated cults to Philip not only as a means to show acceptance towards the power they were suddenly subjected to but also to get accustomed to the new circumstances. A parallel can be drawn between these cities and the province of Macedonia which dealt with the newly established Roman dominance in a similar way. While during the period of the monarchy, ruler worship was limited to the cities outside the periphery of the old kingdom, during the imperial period it took on a central character with formal institutions and was propagated throughout the province. Other than the aforementioned cities, it is possible yet unconfirmed, that Cassandreia might have honoured its founder Cassander with a cult. ${ }^{8}$ It is interesting to note that there is no evidence in Macedonia suggesting that Alexander was deified during the monarchical period, either during his lifetime or after his death, despite his achievements. The Alexander cult became widespread in Macedonia only during the $2^{\text {nd }}$ century AD and played an important role in connecting the Macedonians to their glorious past. But it was a completely new phenomenon which did not have its roots in the Hellenistic period of the province and was a result of the ruling dynasty's great admiration for Alexander as well as the need for the Macedonians to preserve their cultural identity.

When the Romans replaced the monarchy as the ruling power, the Macedonians had to adjust to a new political reality, one that was wrought with more than a century of Rome's civil wars, most of which were fought on Macedonian soil. Funding the Roman army as well as dealing with constant barbarian raids left the economy ravaged.

\footnotetext{
${ }^{7}$ MARI (2008: 241).

8 MARI (2008: 248); Antigonus I and Demetrius I were dedicated cults in Athens in 307 BC. See A. KUHN: Ritual change during the reign of Demetrius Poliorcetes. In: E. Stavrianopoulou (ed.): Ritual and Communication in the Graeco-Roman World. Liège 2006, 265-281.
} 
Although the Romans did not alter the administrative structure of the cities, they divided Macedonia into four regions and placed restrictions on mining and export of timber. While the restrictions did not last for more than a few decades, the situation in Macedonia was not suitable for the settlement of a large number of foreigners. Nevertheless, evidence suggests that by the end of the Republican period small communities of Romans had settled in the cities to take advantage of the land owning and trading opportunities that the region allowed. These communities were not large enough to alter the social structure of the cities and during the Republican period, a clear distinction was maintained between the Roman communities and those of the locals. An inscription from Apollonia dating to $106 \mathrm{BC}$ records a donation made to the city by a certain Maarkos Leukilios, son of Maarkos, to fund the gymnasium of the city. He had also adopted the Greek name Demetrios and the designation 'Roman' which was used synonymously with the word 'negotiator', signifying a trader, appears next to his name. ${ }^{9}$ Considering that he chose to mention the name Demetrios by which he was probably more familiar amongst the local population could indicate that during this period there was a very small community of Romans in Apollonia, allowing them to be known on a first name basis. In cities with larger communities of Romans such as Beroia and Thessaloniki, the locals be-

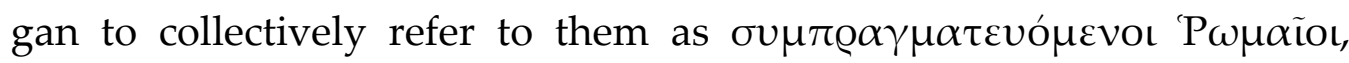

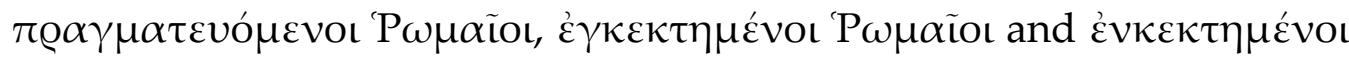

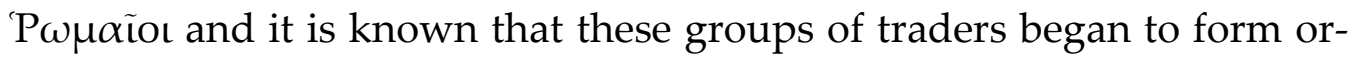
ganisations called the conventus civium Romanorum. These organisations provided the Romans not only the opportunity to socialise with those of a shared background but also to integrate themselves into the social and political lives of the cities. ${ }^{10}$ Members of the conventus came to be regarded as a new group of elite and inscriptions from well into the reign of Augustus suggest that they jointly issued decrees along with the cities honouring important Roman officials and Augustus. The inscriptions concerning associations from the imperial period show that they were structured organisations with a clear hierarchy and administrative posi-

\footnotetext{
${ }^{9}$ YOUNI (2013: 349-350).

10 WILSON (1996).
} 
tions were normally patterned on the structure of the city. ${ }^{11}$ It is unlikely that the associations during the Republican period were as structured as those during the imperial period, being rather simple organisations that acted as compensation for individuals who had left Rome but needed a social space that connected them to their homeland, thus maintaining a strong and visible collective Roman identity within the cities. For the local inhabitants of the cities, making decisions alongside the conventus would have given them the opportunity to interact with the Roman communities that were growing in importance and would have also acted as compensation for the lack of influence they had over their own political affairs.

Another change to be seen on the socio-political and religious fronts is the introduction of the cult of Roma in the Macedonian cities. During the imperial period the image of Roma appeared on the coins of Amphipolis, Thessaloniki and Pella. ${ }^{12}$ There is no evidence for a centrally organised cult so each city would have independently taken the initiative to show their acceptance towards Roman rule. It was customary of the Greeks to flatter a new power with divine honours, as did Amphipolis and Philippi during the reign of Philip II, and while this was a conscious political choice to maintain a beneficial relationship with those who held authority, it was also a means to accommodate a foreign power within their own traditions. It also became customary in the Macedonian cities to honour influential Romans with the titles of 'euergetes' and 'soter'. These titles were reserved for kings during the period of the monarchy but evidence from the Republican period shows that seven officials were honoured with them (the constant barbarian raids gave the Roman officials several opportunities to save the cities due to which most individuals honoured as euergetes and soter are officials in the army). ${ }^{13}$

The social changes during the late Hellenistic period, while minimal, paved the way for greater changes that were to take place in the cities of Macedonia during the imperial period. The newly settled com-

\footnotetext{
11 NigDELIS (2010: 27).

12 KREMYDI-SiCILIANOU (2005: 97).

13 XYDOPOULOS (2018: 11).
} 
munities of Romans did not change the religious landscape of the cities and neither did Latin come close to replacing the use of Greek. Most of the inscriptions from this period (and the imperial period) are in Greek and a considerably lower number are bilingual or in Latin. A notable exception is seen in the Roman colonies such as Philippi, where most inscriptions are in Latin. But Philippi is known to have had a stronger Roman influence compared to the other Macedonian cities where the use of Greek was predominant. But this should not lead us to underestimate the influence Latin would have had on the population of the cities because after all Latin was the official language of the centre. And similar to how important constant communication with the cities was during the monarchical period, Roman authority too would have depended on the provincial governor (or other important Roman officials) to communicate with the civic authorities and they would have done so in Latin. ${ }^{14}$ And not just civic authorities or the elite but members of the lower classes too would have often come across communication in Latin while working with Roman traders, though the latter would have eventually learnt Greek. Thus, even though Greek remained the standard language of communication under Roman rule, the use of Latin would have also been gradually incorporated into regular civic life as did other aspects of Roman presence such as the architecture, use of Roman names and the emperor cult.

\section{The expression of identities during the imperial period}

After the defeat of Antony at Actium in 30 BC, which marked the end of Rome's civil wars and the beginning of the sole leadership of Augustus over the empire, conditions in Macedonia began to improve both economically and politically. Thessaloniki, which was declared a free city in $42 \mathrm{BC}$ as a reward for not siding with Brutus and Cassius, became the seat of the provincial governor. It flourished in the coming centuries due to its favourable location ${ }^{15}$ - not only did it have a large port but also the

\footnotetext{
${ }^{14}$ ANDO (2010: 27).

${ }^{15}$ ADAM-VELENI (2011: 548).
} 
Via Egnatia which linked several important trading cities passed within close proximity to the city. ${ }^{16}$

Thessaloniki attracted a large number of traders from Rome and from other parts of Italy ${ }^{17}$ and its population is considered to be cosmopolitan, including Southern Greeks, people from Asia Minor, Thracians and a small Jewish community. The flourishing of the economy led to increasing urban development and an extensive building programme was undertaken during the Severan period. Many prominent members of the local aristocracy obtained Roman citizenship and held important provincial posts, such as the Geminii and the Claudii which were two of the most prominent families from Thessaloniki known from several inscriptions and whose members held posts such as the Macedoniarch and agonothetes of emperor cult festivals. ${ }^{18}$ The only city that could rival Thessaloniki-and their rivalry was well known-was Beroia, seat of the Macedonian koinon. The koinon during the imperial period was responsible for the propagation of the imperial cult and an inscription from the city suggests that by the time of Nerva, Beroia had been given the honours of being the sole neokoros and metropolis in Macedonia. ${ }^{19}$ It is possible that it was around this time the imperial cult was established as a centrally organised cult in the province and the koinon minted coins in its name and also regularly held festivals and games.

Another change to occur in the province was the establishment of the colonies of Philippi, Pella, Cassandreia, Dion and Stobi which were granted ius italicum and became home to a large number of veterans who were given generous amounts of land by Augustus. Though these cities were not as prominent as Thessaloniki and Beroia, they remained

\footnotetext{
16 ADAM-VELENI (2003: 121).

${ }^{17}$ For the origins of the traders see O. SALOMIES: Contacts between Italy, Macedonia and Asia Minor During the Principate. In A. D. Rizakis (Ed.), Roman Onomastics in the Greek East. Social and Political Aspects. Meletemata 21. Athens 1996, 111-127 and A.

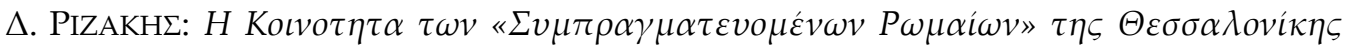

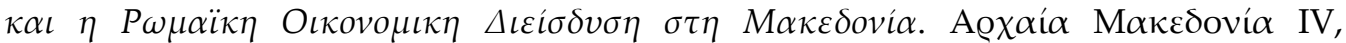

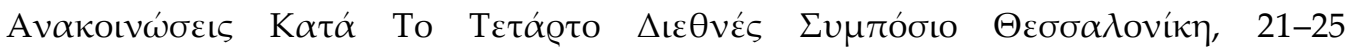

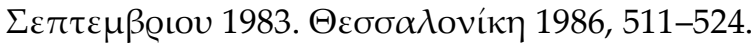

${ }^{18}$ NigDELIS (1996: 129-141).

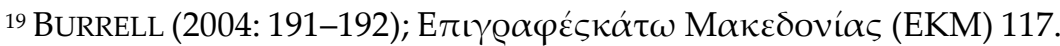


important trading centres for a few centuries under Roman rule. Regarding the population, evidence from the colonies suggest that while prominent Romans became the new elite, the local population became the peregrini and as Rizakis has said, 'foreigners in their own land'. ${ }^{20}$

The provincial government had not laid out a structural set of rules by which the province was to be governed by. Instead it was dependent on the local elite for the administration of the cities and the smooth functioning of the government depended on the constant communication between the centre and the civic elite. Under these circumstances, the latter who acted as mediators between the Roman government and the mass population of their cities, found the opportunity to express a dual identity: on the one hand they served Rome and were admirers of Roman policies but on the other, they were faithful to their cities and worked for the betterment of their communities. ${ }^{21}$ While these identities might seem contradictory, they were in fact complimentary since Rome's policies rather than being detrimental to local tradition, allowed them to prosper. According to Ando, the success of the empire lay in being able to manage diversities, and localism was supported and even encouraged by Rome in order to prevent solidarity amongst the diverse communities under the empire which in turn prevented them from unifying to cause any major threats to the centre. ${ }^{22}$ It is true that along with supporting local communities the Romans also supported or, in any case, tolerated rivalry between them which existed due to the communities vying for special recognition and favours from the emperor. Alongside Ando's suggestion, it is also possible that the Romans recognised that an effective way to govern a province was to depend on the local aristocracy and give them a certain amount of power as long as they recognised that the real power lay in the hands of Rome. Moreover, while the Romans recognised their own political dominance, Greek culture and paideia were looked to with admiration particularly by Philhellene emperors such as Hadrian and those of the Severan dynasty. This gave the Romans a reason to not only preserve local communities but to

\footnotetext{
${ }^{20}$ RIZAKIS (1998: 599-617).

${ }^{21}$ RIZAKIS (2015: 143-145); RIZAKIS (2007: 317-330).

22 ANDO (2010: 18).
} 
also participate in their traditions. Nonetheless, this mutual relationship opened the doors to high ranking provincial positions for the local aristocrats and brought them in the contact with the elite of the Roman society, sometimes even the emperor.

A perfect example of this relationship is Quintus Popilius Python who was high priest of the cult of the emperor and agonothetes of the Macedonian koinon and served as the ambassador to the emperor Nerva on behalf of the Beroians to request him that Beroia should be the only city in Macedonia to hold the titles of neokoros and metropolis. Since his embassy was successful Beroia honoured him with a decree which mentions many of his services towards the city and to the Macedonians. During his term as high priest he paid the capital tax of the province and also bore the expense for the repair of roads. He organized games to show talents, theatrics and athletics and also organized beast fights with local and exotic animals. Moreover, during a period of wheat harvesting he provided grain at low prices and distributed food for the Macedonians who gathered at banquets in Beroia. ${ }^{23}$ Such benefactions were extremely expensive and could only be undertaken by the highest echelons of provincial society.

During the Republican period it is unknown whether the Macedonians desired Roman citizenship or if they believed that they could have the privilege of becoming citizens of Rome since there is no evidence of citizenship grants within the province from this period. But as the number of citizenship grants increased during the imperial period, being a Roman citizen became a marker of a person's political distinction and eventually a necessity for those wanting to climb the political and social ladder. Quintus Popilius Python who is mentioned earlier had gained Roman citizenship as is evident by the use of his tria nomina but was a native of Beroia, judging from his use of a Greek cognomen. ${ }^{24}$ It is impossible to tell whether Python and others who became Roman citizens identified with being Roman just as they identified with their Macedonian and civic identity (and this would have differed considerably between individuals) but acting as Roman citizens would have definitely

\footnotetext{
${ }^{23}$ EKM 117 op. cit.

24 TATAKI (1988: 448).
} 
added a new sense of identity, one that more likely had political leanings than cultural. This dual identity, as I mentioned earlier, was expressed by adopting certain aspects of Roman tradition while continuing to follow those that were firmly rooted in local culture.

The elite adopted Roman names and proudly displayed their status as citizens of Rome. They also participated in the cult of the emperor and though this cult has been linked to the Hellenistic ruler cults, the scale of the celebrations was much grander than anything that had existed during the Hellenistic times. Celebrations which took place regularly included festivals, gladiatorial and animal fights, athletic games and other spectacles which lasted for days and were attended by people from all around the province. ${ }^{25}$ Also, never before in the Mediterranean had a single cult united such as vast expanse of territory. Provinces all around the empire minted coins honouring the emperors and built statues of them and the emperor cult was one of the aspects of Roman rule which created a sense of homogeneity within an empire comprising of diverse cultures, that is before Caracalla declared in 212 AD that all free citizens of the empire were to become Roman citizens. Surviving coins from the Macedonian cities depict the emperors being honoured as gods and issues from Thessaloniki and Amphipolis also depict the close family members of the emperor. ${ }^{26}$ It was the responsibility of the civic elite to choose the themes that were to be depicted on the coins and the images are a reflection of their political ideology. It should be noted that the issues from the colonies, where the Romans formed the ruling class, did not emphasise the divinity of living rulers since Romans deified emperors after their death. ${ }^{27}$ The only official form of emperor cult in Rome was the worship of the Divi (emperors divinized after their death). It was also the responsibility of the elite to finance and erect statues of the emperors. This required the city officials to ratify a decree and send it to the emperor asking for his permission for the statue to be erected. The emperor could choose to grant their request, reject it or propose changes

\footnotetext{
${ }^{25}$ AlLAMANI-SOURI (2003: 100-101).

${ }^{26}$ KREMYDI-SICILIANOU (2005: 98).

27 KREMYDI-SiCILIANOU (2005: 99).
} 
to be made to the statue. ${ }^{28}$ The emperor cult was certainly part of the Greek tradition of cities honouring a foreign ruler as divine in order to comprehend the new circumstances and show their favourable political disposition. But the conditions associated with ruler worship were continuously moulded in accordance with the current socio-political situation, as were the identities of the people of the province.

Displaying their rootedness to their city, the elite undertook acts of euergesia which was a tradition that was widely established in the Greek cities by the time of the Hellenistic period. ${ }^{29}$ Their benefactions included the repair of public roads and buildings, construction of aqueducts, organisation of public festivals, undertaking of building projects within the cities and helping the cities in times of need by lowering the prices of food. Since reciprocity for benefactions was part of Greek culture ${ }^{30}$ the benefactors often along with their family members were honoured by their cities which erected statues and honorary decrees in public spaces. But it was not only through euergetism that the elite showed patriotism. The standard practise for the Greeks who used the tria nomina was to use a Greek cognomen instead of a Latin one, where they retained their original Greek name as the cognomen, although there are exceptions to this rule (some chose to adopt a Latin cognomen). In Macedonia many of them even chose to use traditional Macedonian names and the name Makedon became quite popular in the province. Such is the case of Geminius Makedon of the illustrious Geminii family that has been mentioned earlier. From inscriptions he is known to have lived in Thessaloniki during the end of the second and beginning of the third century AD. An honorary inscription dedicated to Geminius Makedon, who was the most important family member, by his daughter mentions that he was not only archon and first gymnasiarch of Thessaloniki but also the high priest of the emperor cult and the first person from Thessaloniki to head the Panhellenion created by Hadrian. The emperor had also made

\footnotetext{
28 AlLAMANI-SOURI (2003: 110).

${ }^{29}$ For the origins of euergetism in the Greek cities see M. GYGAX: Benefaction and Rewards in the Ancient Greek City. The origins of Euergetism. Cambridge 2016.

30 DEENE (2013: 76).
} 


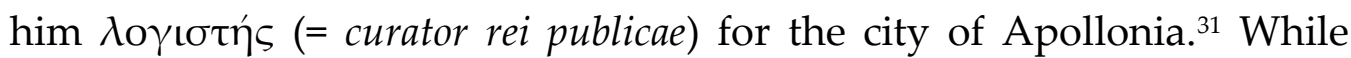
this inscription refers to him by his tria nomina with a second cognomen, i.e. T. Aelius Geminius Makedon, the inscription on his sarcophagus refers to him as Geminius Olympos ${ }^{32}$ which signifies that Olympos was his original Macedonian name. ${ }^{33}$ Names are an important part of a person's identity and the use of Makedon as a second cognomen and particularly the use of Olympos, which was an ancient Macedonian name, suggests that he bore a strong sense of philopatria. Also, as Rizakis suggests, how Greeks conceived their Roman identity differed according to space and time and the character of the document. ${ }^{34}$ Thus, the difference in the use of names on the honorary decree and the sarcophagus is also significant in this case. The purpose of the honorary decree which used his tria nomina was to outline his political achievements and exhibited his political identity but on the sarcophagus, it would have been more important to him to display his rootedness to his homeland. Moreover, his daughter's name was Olympia which was also an ancient Macedonian name.

Geminius Makedon and his family lived during a period which saw a rise in display of patriotism on the part of the Macedonians. One of the reasons for this was the renewed interest of the Severan dynasty, particularly Caracalla and Alexander Severus, in Alexander the Great. The koinon held games to honour the Macedonian king and also minted coins depicting Alexander and his mother Olympias and themes that related to them. ${ }^{35}$ But while the pro-Macedonian politics of the emperors were certainly responsible for encouraging the Macedonians to display pride in their culture, it was also the society as it existed during the imperial period that led to such mannerisms. The Republican period did not see much intermingling between the Roman and the Macedonian communities but two centuries of Roman rule had intertwined their cultures and even though the Macedonian culture had clearly not assimi-

\footnotetext{
${ }^{31} \mathrm{IG} X, 21181$.

${ }^{32}$ IG X,2 1628.

${ }^{33}$ NigDELIS (1996).

${ }^{34}$ RIZAKIS (2001: 566).

35 BURRELL (2004: 193-196).
} 
lated into that of the Romans, they probably felt the need to culturally distinguish themselves and the most ideal way to do this was by looking back to their glorious past. This expression of patriotism was not done in order to resist Roman rule (the Macedonians would have felt safe to express their cultural identity knowing that after more than a century of Roman rule it would not be perceived as a threat by the Romans) but it was a way of dealing with the fear that the loss of political control would eventually lead to the loss of their cultural identity. Thus, as Koulakiotis has said, the cities were caught between 'recognising Roman sway and asserting Greek patriotism'. ${ }^{36}$ The Macedonians also turned to religion to ensure the continuation of their cultural identity. Religious expression would have also provided them a sense of independence through the assurance that not all aspects of their lives were controlled by Roman rule. Coins from the first to the third century from various cities depict local gods and cults including Zeus, Athena, Artemis Tauropolos, Pan, Poseidon, Ammon and Dionysus. ${ }^{37}$ Cassandreia began to mint coins depicting the local deity Ammon as early as the reign of Claudius and continued to produce these types until the reign of Philip the Arab. ${ }^{38}$ These cults show not only the increasing trend to depict local deities but also the revival of older cults such as the depiction of Poseidon on the coins of Cassandreia from the reign of Marcus Aurelius and the depiction of Kabeiros on the issues of Thessaloniki under the Severans. Kabeiros was not a Macedonian but a Samothracian god in whom the Macedonian royal family had showed an interest and during the imperial period this cult was elevated to the status of a state cult. Its importance is apparent from the coinage of Thessaloniki which minted coins depicting Kabeiros on the reverse and the emperor and his family members on the obverse. ${ }^{39}$

While Roman religion did not gain widespread popularity in the Macedonian cities (Roman myths are depicted only on the coins of Philippi), certain Roman festivals became a part of provincial culture. An

\footnotetext{
36 KOULAKIOTIS (2010: 93).

${ }^{37}$ KREMYDI-SICILIANOU (2005: 103-106).

38 DAUBNER (2014: 114-115).

39 EDSON (1948: 188-204).
} 
inscription from Philippi attests to the celebration of Rosalia which was a Roman festival celebrated around the empire during which respects were paid to dead family members. ${ }^{40}$ The inscription states that Valeria Mantana, widow of Aurelios Zipyron gave 150 denarii to the association of the god Souregethes to light a tomb side fire during the festival of rosalia..$^{41}$ Rosalia was held in May or June and usually involved family members or members of an association scattering roses on graves and decorating funerary monuments with them. ${ }^{42}$ Another inscription concerning rosalia comes from Thessaloniki in which a priestess of a Dionysiac association states that each mystes of the association was responsible for placing on her grave a crown of roses. ${ }^{43}$ A Roman cult worth mentioning is the cult of Silvanus which gained acceptance in Philippi. A few fragmentary inscriptions mentioning the cult and names of members of an association dedicated to it have been found at the sanctuary dedicated to Silvanus on the acropolis of the city. ${ }^{44}$ Silvanus was the Roman god of agriculture, woods and boundaries and hundreds of inscriptions and statues dedicated to his worship have been found around the empire. ${ }^{45}$ This cult was never incorporated into the public cults of Rome and did not involve the elite but was popular amongst the lower classes of society. ${ }^{46}$ The inscription found at Philippi included the names of several freedmen and four slaves. ${ }^{47}$ Since the elite were never involved in this cult, the freedmen and slaves from Rome popularised it amongst the lower classes of Philippi but there is no evidence suggesting that this cult ever became popular in any other Macedonian city.

Unlike the elite, the lower classes of citizens which made up the bulk of the population had no political motivations for maintaining a dual identity since most of them could not aspire to gain prominent places in the social or political structure of the society (some wealthy

\footnotetext{
${ }^{40}$ KLOPPENBORG-AsCOUGH (2011: 325-329).

${ }^{41}$ KLOPPENBORG-ASCOUGH (2011).

42 TONYBEE (1971: 63).

${ }^{43}$ IG X,2 1260.

${ }^{44}$ KLOPPENBORG-AsCOUGH (2011: 315-324).

${ }^{45}$ DORCEY (1989: 143).

${ }^{46}$ DZINO (2012: 263).

${ }^{47}$ KLOPPENBORG-AsCough (2011: 323).
} 
freedmen did attain prominent positions but this was uncommon). However, they constantly interacted with Roman communities and it is inevitable that they were influenced by Roman culture. Some would have made a conscious choice to integrate aspects of Roman traditions into their daily lives while others would have followed traditions only because they had become the latest cultural trends.

Associations during the imperial period allowed the admission of the local inhabitants of the cities as well as foreigners along with the Romans and provided a cultural space for individuals to interact with others who followed the same cults or professions (depending on the type of association). Communal eating and drinking was one of the main features of associations and the members also participated in public sacrifices and rituals, particularly Dionysiac associations. ${ }^{48}$ For example, members of Dionysiac associations re-enacted the myth of ascension of Dionysus' mother Semele from the underworld and members of associations dedicated to Aphrodite re-enacted the sacred marriage between Eros and Aphrodite. ${ }^{49}$ This inclusive environment would have been one of the reasons why Roman citizenship became more widespread and was granted (in limited numbers) to members not belonging to the elite, as attested by the onomastic data in the epigraphic evidence. It shows that some of the members of the local population entered into ties with Roman families either through marriages, friendship or a political relationship and the latter helped them acquire Roman citizenship. Elements of Roman names also began to be used as individual names by people of peregrine status, particularly in cities with a strong Roman presence such as the colonies. ${ }^{50}$

\section{Conclusion}

The Macedonian society under Roman rule was constantly evolving. The small communities of Romans in the cities who were regarded as outsiders during the Republican period grew considerably during the imperial period and they adapted themselves to provincial society and

\footnotetext{
48 WILSON (1996).

${ }^{49}$ NigDELIS (2010: 29-30).

50 RIZAKIS (2019: 247-249).
} 
their descendants were no longer regarded as foreigners. In such a society where both the Romans and the Macedonians coexisted, it is inevitable that they adopted elements of each other's cultures, leading to the creation of new identities and new forms of expression. In order to show their acceptance to Roman politics and traditions, the Macedonians took on a political identity which found expression in the use of the tria nomina, cults dedicated to Roma and the emperors and their celebrations and in some places with a strong Roman influence, even the acceptance of Roman cults and the use of Latin. But as these communities intermingled, the Macedonians not only displayed their loyalty towards their homeland but also emphasised their cultural distinction. Acts of benefactions, the use of Greek cognomen, the display of local cults on coins and a renewed interest in their glorious past were means of expression of an identity that stressed their rootedness to their homeland. But it should be kept in mind that the expression of these identities was taking place within a society where as mentioned earlier, the locals were constantly interacting with the Romans and influencing each other's cultures. Euergetism, which was a Greek tradition originating in the polis, became an integral part of Roman political policy to ensure the smooth functioning of the civic administration and urban development of cities in the province. Gladiatorial fights which were a Roman tradition became a part of provincial culture and were held in conjunction with athletic games and other spectacles to celebrate the emperor cult and other local festivals. It is true that it becomes increasingly difficult to draw a clear distinction between both communities but it is also true that neither of them was Hellenised or Romanised. The Macedonians continued to express their own distinct identity and their expression did adopt elements of Roman culture. This was not because they were becoming Roman but was a consequence of an evolving society in which certain Roman traditions became part of provincial culture and like the Romans themselves, were no longer regarded as foreign.

\section{Bibliography}

Adam-Veleni 2003 P. Adam-Veleni: History and Town Planning. In: D. V. Grammenos, P. Adam-Veleni (ed.): Roman Thessaloniki. Thessaloniki 2003, 121-176. 
AdAm-Veleni 2011 P. AdAm-Veleni: Thessaloniki. In: R. J. Lane Fox. (ed.): Brill's Companion to Ancient Macedon: Studies in the Archaeology and History of Macedon, 650 BC-300 AD. Boston 2011, 545-562.

ALLAMANI-SOURI 2003 V. AllAMANI-SOURI: The Province of Macedonia in the Roman Imperium. In: D. V. Grammenos, P. Adam-Veleni (ed.): Roman Thessaloniki. Thessaloniki 2003, 67-119.

ANDO 2010 C. ANDO: Imperial Identities. In: T. Whitmarsh (ed.): Local Knowledge and Microidentities in the Imperial Greek World. Cambridge 2010, 17-45.

BAYNHAM 1994 E. BAYNHAM: The Question of Macedonian Divine Honours for Philip II. Mediterranean Archaeology 7 (1994) 35-43.

BurRell 2004 B. BuRRELl: Koinon of Beroia. In: Neokoroi: Greek Cities and Roman Emperors. Boston 2004, 191-197.

CARNEY 2000 E. CARNEY: The Initiation of Cult for Royal Macedonian Women. Classical Philology 95 (2000) 21-43.

CHANIOTIS 2003 A. CHANIOTIS: The Divinity of Hellenistic Rulers. In: A. Erskine (ed.): A Companion to the Hellenistic World. Oxford 2003, 431-445.

DAUBNER $2014 \quad$ F. DAUBNER: On the Coin Iconography of Roman Colonies in Macedonia. N. T. Elkins and S. Krmnicek (ed.): Tübinger Archäologische Forschungen 16 (2014) 109-119.

DEENE 2013

M. DEENE: Seeking for honour(s)? The exploitation of philotimia and citizen benefactors in classical Athens. Revue belge de philologie et d'histoire 91 (2013) 69-87.

DORCEY 1989 P. F. DORCEY: The Role of Women in the Cult of Silvanus. Numen 36/2 (1989) 143-155.

DZINO 2012 D. DZINO: The cult of Silvanus: rethinking provincial identities in Roman Dalmatia. Vjesnik arheološkog muzeja u Zagrebu 45(1) (2012) 261-279.

EDSON 1948 C. EDSON: Cults of Thessalonica (Macedonica III). The Harvard Theological Review 41/3 (1948) 153-204.

GOUNAROPOULOU-HATZOPOULOS 1998

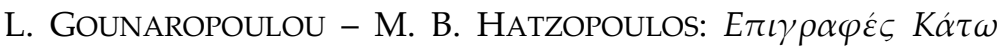

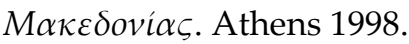

GygAX 2016 M. GyGAX: Benefaction and Rewards in the Ancient Greek City. The origins of Euergetism. Cambridge 2016.

KLOPPENBORG-ASCOUGH 2011

J. S. Kloppenborg - R. S. Ascough: Greco-Roman Associations: Texts, Translations, and Commentary I Attica, Central Greece, Macedonia, Thrace. Berlin 2011.

KOULAKIOTIS 2010 E. KOULAKIOTIS: Approaching cultural identities in the Roman world: Alexander the Great and other Macedonian kings in the literary sources. In: I. Stefanidis, V. Vlasidis, E. Kofos (ed.): Macedonian Identities Through Time. Thessaloniki 2010, 75-101. 
KREMYDI-SICILIANOU 2005

S. KREMYDI-SICILIANOU: Belonging to Rome, remaining Greek: Coinage and Identity in Roman Macedonia. In: C. Howgego, A. Burnett, V. Heuchert (ed.): Coinage and Identity in the Roman Provinces. Oxford 2005, 95-106.

MARI 2008

MILLAR 1984

NigDELIS 1996

NigDELIS 2010

RIZAKIS 1986

RIZAKIS 1998

RIZAKIS 2007

RIZAKIS 2008

RIZAKIS 2015

RIZAKIS 2019

SALOMIES 1996
M. MARI: The Ruler Cult in Macedonia. Studi ellenistici 20 (2008) 219-268.

F. MiLLAR: State and Subject: The Impact of Monarchy. In: F. Millar E. Segal (ed.): Caesar Augustus Seven Aspects. Oxford 1984, 3760.

P. NigDeLIS: Geminii und Claudii: die Geschichte zweier führender Familien von Thessa-loniki in der späteren Kaiserzeit. In: A. D. Rizakis (ed.): Roman Onomastics in the Greek East. Social and Political Aspects. Meletemata 21. Athens 1996, 129-141.

P. NIGDELIS: Voluntary associations in Roman Thessalonikē: in search of identity and support in a cosmopolitan society. In: Ch. Bakirtzis S. J. Friesen - L. Nasrallah (ed.): From Roman to Early Christian Thessalonikē: Studies in Religion and Archaeology. Cambridge 2010, 13-47.

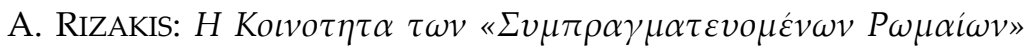

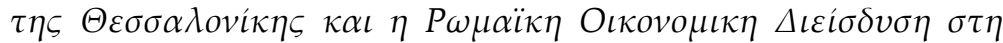

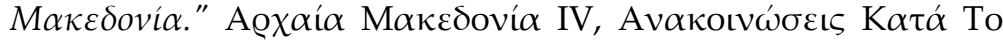

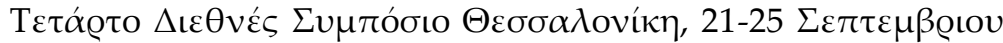
1983 (1986) 511-524.

A. RIZAKIS: Incolae-paroikoi : populations et communautés dépendantes dans les cités et les colonies romaines de l'Orient. Revue des Études Anciennes. Tome 100 (1998) 599-617.

A. RIZAKIS: Urban Elites in the Roman East: Enhancing Regional Positions and Social Superiority." In J. Rüpke (ed.): A Companion to Roman Religion. Oxford 2007, 317-330.

A. RIZAKIS: Noms romains, identité culturelle et romanisation dans les provinces orientales de l'Empire. ASAtene LXXXVII, serie III, 9vol. I (2008) 565-580.

A. RIZAKIS: The Greek Ruling Class under the Empire: A Privileged Mediator between Rome and the Cities. Kodai Journal of Japanese History 16 (2015) 143-159.

A. RIZAKIS: New Identities in the Greco-Roman East. In R. Parker (ed.): Changing Names Tradition and Innovation in Ancient Greek Onomastics. Oxford 2019, 237-257.

O. SALOMIES: Contacts between Italy, Macedonia and Asia Minor During the Principate. In A. D. Rizakis (ed.): Roman Onomastics in the Greek East. Social and Political Aspects. Meletemata 21. Athens 1996, 111-127. 
SMITH 1995

TATAKI 1988

TONYBEE 1971

WILSON 1996

XYDOPOULOS 2018

YOUNI 2013
A. D. SMITH: The Formation of National Identity. In H. Harris (ed.): Identity: Essays Based on Herbert Spencer Lectures Given in the University of Oxford. Oxford 1995, 129-153.

A. TATAKI: Ancient Beroea: Prosopography and Society. MEAETHMATA 8. Athens 1988.

J. M. C. TONYBEE: Death and Burial in the Roman World. Maryland 1971.

G. Wilson: Voluntary Associations: An Overview. In J. S. Kloppenborg, S. G. Wilson (ed.): Voluntary Associations in the GraecoRoman World. London 1996, 1-15.

I. XyDOPOUlOS: Euergetes and Euergesia in Inscriptions for Public Benefactors from Macedonia. Ancient West and East 17 (2018) 83118.

M. Youni: Negotiatores in Roman Macedonia. In V. Leontaritou, K.

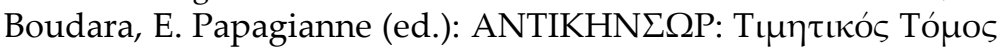

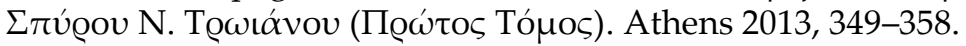

